\title{
MANAJEMEN LABA DAN ANALISIS FAKTOR YANG MEMPENGARUHINYA
}

\author{
aSagung Oka Pradnyawati, butu Kepramareni, 'Kadek Maysi \\ ${ }^{a b c}$ Universitas Mahasaraswati, Denpasar \\ sagungoka@unmas.ac.id
}

\begin{abstract}
ABSTRAK
Manajemen laba dan analisis faktor yang mempengaruhinya. Research ini bertujuan untuk menguji faktor-faktor yang dapat mempengaruhi manajemen laba dengan menggunakan perencanaan pajak, leverage, ukuran perusahaan dan profitabilitas. Penelitian ini menggunakan data keuangan dari perusahaan manufaktur yang tercatat pada papan utama www.idx.co.id sebagai subjek utama. Hasil penelitian ini menunjukkan bahwa (1) perencanaan pajak tidak berpengaruh terhadap manajemen laba (2) profitabilitas berpengaruh positif terhadap manajemen laba (3) leverage tidak berpengaruh terhadap manajemen laba, serta (4) ukuran perusahaan tidak berpengaruh terhadap manajemen laba
\end{abstract}

Kata Kunci: Leverage, Manajemen Laba, Perencanaan Pajak, Profitabilitas, Ukuran Perusahaan

\section{PENDAHULUAN}

Dunia usaha yang berkembang semakin maju menjadikan laporan keuangan sebagai media penting dalam pengambilan keputusan bagi setiap perusahaan. Laporan keuangan memberikan suatu informasi yang menggambarkan kondisi keuangan suatu perusahaan dimana informasi tersebut dapat dijadkan sebagai gambaran kinerja sebuah perusahaan. Laporan keuangan yang ditampilkan dianggap memiliki arti penting dalam hal menilai kondisi sebuah perusahaan, sehingga pihak-pihak yang membutuhkan dapat mengakses laporan keuangan dengan mudah dan dapat dijadikan bahan pertimbangan dalam pengambila keputusan (Fahmi, 2011). Menurut Rahmawati (2010) fokus utama dalam laporan keuangan adalah informsi laba, karena menyediakan informasi mengenai kinera keuangan suatu perusahaan selama satu periode. Bagi seorang kreditur dan investor, informasi laba membantu mereka dalam menevaluasi kinerja perusahaan, memprediksi laba di masa yang akan datang, dan juga untuk memperhtungkan risiko investasi atau pinjaman kepada perusahaan.

Indikator yang seringkali digunakan untuk menilai kinerja manajemen adalah laba perusahaan. Pentingnya laba tidak hanya digunakan untuk menilai kinerja manajemen tetapi juga sebagai pertimbangan dalam pengambilan keputusan oleh investor ataupun sebagai acuan untuk menentukan besar kecilnya pajak yang akan dibayarkan oleh perusahaan, tidak heran jika laba dapat digunakan sebagai target rekayasa untuk tindakan oputunis mnajemen perushaan dan memaksimumkan tujuannya.Tindakan oportunis dapat dilakukan salah satunya dengan memilih kebjkan akuntansi tertentu yang berakibat pada mudahnya mengatur laba perusahaan, baik menaikan, menurunkan ataupun meratakan sesuai keinginan. Perilaku manajemen tersebut dikenal dengan istilah manajemen laba (earnings management).

Maraknya fenomena manajemen laba (earnings management) yang terjadi menandakan bahwa tindakan manajemen laba masih banyak ditemukan di berbagai perusahaan terutama pada perusahaan sektor manufaktur, salah satu fenomena manajemen laba yang pernah terjadi di Indonesia terjadi pada PT Kimia Farma dimana bermula dari tahun 2002, perusahaan melakukan kesalahan pencatatan pada penjualan yang mengakibatkan overstated laba senilai Rp 32,7 miliar untuk period akuntansi di Tahun 2001. Jumlah laba 
yang dilaporkan sebelumnya adalah Rp 132 miliar dan setelah dilakukan audit kembali, laba perusahaan hanya sebesar Rp 99,5 miliar (Anggana dan Prastiwi, 2013).

Fenomena lainnya terkait praktik manajemen laba adalah pada PT. Ades Alfindo Tbk. Berita ini mulai terkuak saat manajemen baru PT. Ades Alfindo Tbk menemukan adanya inkonsistensi pencatatan pada penjualan periode 2001-2004. Sebelumnya pada Juni 2004 sempat terjadi perubahan manajemen dengan masuknya Water Partners Bottling Co (perusahaan group The Coca Cola Company dan Nestle SA) yang kepemilikan sahamnya sebesar $65,07 \%$. Pergantian pemilik inilah yang berhasil menguak inkonsistensi pencatatan dalam laporan keuangan periode 2001-2004 dengan indikasi dilakukan oleh manajemen sebelumnya. Berdasarkan penyelidikan ditemukan setiap kuartal angka penjualan lebih tinggi antara 0,6-3,9 juta galon dibanding angka produksi. Manajeman baru juga melaporkan angka penjualan riil pada tahun 2001 yang diperkirakan lebih rendah Rp. 13 miliar dari yang dicatat. Sementara tahun 2002 perbedaan angka mencapai Rp. 45 miliar, dan pada tahun 2003 senilai Rp. 55 miliar. selanjutnya enam bulan pertama tahun 2004 selisih yang terjadi diperkirakan mencapai Rp. 2 miliar. Kesalahan tersebut tidak terdeteksi dari pengamatan publik karena PT. Ades Alfindo Tbk tidak memasukkan volum penjualan dalam laporan keuanan yang telah diaudit. Sebagai akibatnya, laporan keuangan yang disajikan pada periode 2001-2004 lebih tinggi dari yang seharusnya dilaporkan (Detik finance, 2004). Kedua fenomena di atas menunjukan bahwa praktik manajemen laba bukanlah hal yang baru ditengah dunia bisnis di Indonesia.

Laba berhubungan dengan pajak yang harus dibayarkan oleh perusahaan sehingga perencanaan pajak dapat menjadi salah satu faktor yang mempengaruhi terjadinya manajemen laba. Perencanaan pajak merupakan media untuk memenuhi kewajiban perpajakan dengan tepat, akan tetapi jumlah pajak dapat ditekan serendah mungkin untuk memperoleh laba dan likuiditas yang sesuai dengan keinginan pihak manajemen. Sumomba (2010) berhasil membuktikan bahwa perencanaan pajak memberikan pengaruh positif terhadap manajemen laba yang diukur menggunakan tingkat retensi pajak sehingga dapat mendeteksi praktik manajemen laba sebagai bentuk respon atas perubahan tarif pajak dari $28 \%$ ke $25 \%$ sesuai dengan UU No. 36 Tahun 2008 . Selain perencanaan pajak, penggunaan dana dari utang untuk meningkatkan return (leverage) juga dapat menjadi pengaruh dilakukannya manajemen Leverage adalah penggunaan aset juga sumber dana oleh perusahan yang memiliki biaya (beban tetap) dengan maksud dapat meningkatkan keuntungan potensial pemegang saham (Novianus, 2016). Perusahaan dengan tingkat leverage yang tinggi termotivasi untuk melakukan manajemen laba agar terhindar dari pelanggaran hutang. Penelitian terdahulu terkait dengan leverage dan manajemen laba yang dilakukan oleh (Ramadhani, 2007) menunjukkan bahwa leverage berpengaruh positif terhadap manajemen laba. Penelitian lainnya yang dilakukan oleh Suyoto (2019) yang menunjukan bahwa leverage berpengaruh negatif terhadap manajemen laba.

Penelitian lainnya menyatakan selain perencanaan pajak dan leverage faktor lain yang dapat memberikan kontribusi atas praktik manajemen laba adalah ukuran perusahaan. Tingkat identifikasi besar atau kecilnya suatu perusahaan atau dikenal dengan ukuran perusahaan dapat didasarkan pada total nilai aktiva, total penjualan, kapitalisasi pasar dan jumlah tenaga kerja (Hilmi dan Ali, 2008). Ukuran perusahaan juga merupakan cerminan dari seberapa besar perusahaan yang berkaitan dengan kemampuan serta peluang perusahaan dalam hal menghasilkan laba (Purwaningrat, 2015). Perusahaan dengan ukuran besar dianggap memilki sumber daya yang lebih besar dan akan menghasilkan net income yang lebih tinggi dibanding denjan perusahaan berukuran kecil. Perusahaan dengan ukuran sedang dan besar juga dinilai kurang memiliki dorongan untuk melakukan manajemen laba dibandingkan dengan perusahaan kecil, karena perusahaan besar dipandang lebih kritis oleh pemegang saham dan pihak eksternal (Handayani, 2009).

Laba suatu perusahaan tidak terlepas dari profitabilitas karena profitabilitas menggambarkan kemampuan perusahaan dalam menghasilkan laba selama satu periode waktu tertentu. Pada umumnya nilai profitabilitas suatu perusahaan dapat digunakan sebagai indikator untuk mengukur kinerja suatu perusahaan. Semakin tinggi profitabilitas suatu 
perusahaan maka kemampuan perusahaan dalam menghasilkan laba juga meningkat. Hubungan antara profitabilitas dengan manajemen laba juga dapat terjadi di saat laba yang diperoleh perusahaan menurun ataupun kecil pada suatu periode, hal ini dapat memicu perusahaan untuk melakukan peningkatan laba dan pendpatan sehingga dapat memperlihatkan pergerakan saham yang baik dan menjaga citra perusahaan di mata investor.

Bedasarkan uraian teori secara teoritis dan empiris tersebut, peneliti tertarik untuk melakukan sebuah penelitian dimana suatu rasio yaitu manajemen laba, akan diteliti variabelvariabel yang mempengaruhinya sehingga hasil penelitian dapat membantu para investor saat melakukan pertimbangan terkait keputusan investasi. Dengan demikian penelitian ini akan diberikan judul "Manajemen Laba Dan Analisis Faktor Yang Mempengaruhinya.

\section{KAJIAN LITERATUR}

\section{Definisi Teori Akuntansi Positif}

Teori akuntansi positif memberikan prediksi yang baik sesuai dengan kejadian nyata yang terjadi. Menurut teori akuntansi positif, prosedur akuntansi yang digunakan oleh perusahan tidaklah harus sama dengan yang lain, namun perusahaan memiliki kebebasan untuk memilih salah satu alternatif prosedur yang telah tersedia untuk meminimalkan biaya kontrak dan memaksimalkan nilai perusahaan. Atas kebebasan yang diberikan tersebut maka menurut (Scott, 2009) manajer memiliki kecenderungan melakukan suatu tindakan yang dalam teori akuntansi positif dinamakan sebagai tindakan oportunis (opportunistic behavior). Teori akuntansi positif dalam Chariri dan Ghozali (2007) menyatakan bahwa ada tiga hubungan keagenan:

1. Antara manajemen dengan pemilik (pemegang saham)

Manajemen yang memiliki jumlah saham yang lebih sedikit dibandingkan dengan investor lainnya, maka manajemen dapat cenderung melaporkan angka laba yang lebih tinggi atau kurang konservatif. Penyebabnya adalah dari sisi prinsipal memprioritaskan dividen atau capital gain atas saham yang dimiliki sementara dari sisi agen (manajer) lebih memprioritaskan penilaian atas kinerja mereka yang baik sehingga dapat memperoleh bonus. Tetapi jika kepemilikan manajer lebih banyak dibanding dengan investor lain, maka manajmen akan cenderung melaporkan laba lebih konservatif, dikarenakan rasa memiliki manajer terhdap perusahan itu cukup besar, maka motivasi manajer adalah lebih mengembangkan perusahaan. Penggunaan metode konservatif akan membuat cadangan tersembunyi yang cukup besar untuk meningkatkan jumlah investasi perusahaan. Aset diakui dengan nilai terendah, yang berarti nilai pasar lebih besar dibandingkan nilai buku.

2. Antara manajemen dengan kreditur

Manajemen pada umumnya melaporkan angka laba lebih tinggi dikarenakan pada umumnya kreditur berangapan bahwa perusahan dengan laba yang tinggi akan dapat memenuhi tanggung jawab atas utang dan bunga secara tepat waktu. Atau dengan kata lain kreditur berpikir tingkat risiko tidak terbayar akan lebih rendah. Laba yang tinggi akan membuat kreditur lebih mudah dalam memberikan pinjaman.

3. Antara manajemen dengan pemerintah Manajer dapat melaporkan labanya secara konservatif. Hal ini dilakukan salah satunya adalah untuk menghindari pengawasan yang lebih ketat dari pemerintah, analis sekuritas serta pihak yang berkepentingan lainnya. Pada umumnya perusahaan yang besar dibebani oleh beberapa konsekuensi. Salah satu contohnya wajib menyediakan pelayanan publik yang lebih baik dan membayar pajak yang lebih tinggi. 


\section{Definisi Manajemen Laba}

Manajemen laba dapat didefinisikan sebagai suatu intervensi dengan maksud tertentu terhadap proses pelaporan keuangan eksternal dengan sengaja untuk memperoleh beberapa keuntungan pribadi. Penelitian ini menggunakan pengujian dengan pengukuran discretionary accrual (DAC) yang diperoleh dari error term total akrual dengan menggunakan model (1991) yang telah dimodifikasi oleh Dechow (1995).

Perhitungan discretionary accruals (DAC) adalah:

a. Menghitung nilai total akrual dengan menggunakan pendekatan arus kas

(Sulistyanto, 2008:225):

TAit $=$ Nit - CFOit

Keterangan:

TAit $\quad=$ Total accrual perusahaan i pada tahun $\mathrm{t}$

Nit = Laba bersih (net income) setelah pajak pada perusahaan i pada tahun $\mathrm{t}$

CFOit $=$ Kas dari operasi (Cash flow operation) perusahaan i pada tahun $\mathrm{t}$

b. Mencari nilai koefisien dari regresi total akrual:

Mengetahui nilai koefisien $\beta 1, \beta 2, \beta 3$, dapat dilakukan dengan teknik regresi. Regresi ini adalah untuk mendeteksi adanya discretionary accruals dan nondiscretionary accruals. Discretionary accrual merupakan perbedaan antara total akrual dengan nondiscretionary accrual. Total akrual kemudian dirumuskan sebagai berikut (Sulistyanto, 2008:226):

TAit/Ait-1 = $\beta 1(1 /$ Ait-1) $+\beta 2((\Delta$ REVit $/$ Ait-1 $)-(\Delta$ RECit $/$ Ait-1 $))+\beta 3($ PPEit $/$ Ait- 1$)+\varepsilon i t$ Keterangan:

TAit $=$ Total akrual perusahaan i pada tahun $\mathrm{t}$.

Ait-1 = Total aset perusahaan i pada tahun $\mathrm{t}-1$.

$\triangle \mathrm{REVit}=$ Pendapatan perusahaan i pada tahun $\mathrm{t}-$ pendapatan pada tahun $\mathrm{t}$.

$\triangle \mathrm{REC}$ it $=$ piutang perusahaan i pada tahun $\mathrm{t}-$ piutang tahun $\mathrm{t}$.

PPEit = aset tetap perusahaan i pada tahun $\mathrm{t}$.

हit $\quad=$ Error term perusahaan i pada tahun $\mathrm{t}$.

c. Menghitung Nondiscretionary Accruals (NDAC)

Perhitungan nondiscretionary accruals (NDAC) dilakukan dengan memasukkan nilai keofisien $\beta 1, \beta 2$ dan $\beta 3$ yang diperoleh dari regresi. Perhitungan dilakukan untuk seluruh sampel perusahaan pada masing - masing periode. Perhitungan nondiscretionary accrual dengan rumus sebagai berikut (Sulistyanto, 2008:226):

NDAit $=\beta 1(1 /$ Ait-1 $)+\beta 2((\Delta$ REVit $/$ Ait-1 $)-(\Delta$ RECit $/$ Ait-1 $)+\beta 3 \quad($ PPEit $/$ Ait-1 $)+\varepsilon i t$

Keterangan:

NDAit $=$ Nondiscretionary accruals perusahaan i pada tahun $\mathrm{t}$

d. Menentukan disctionery accrual

Setelah didapatkan nilai nondiscretionary accruals, menghitung disctionery accruals dapat dilakukan menggunakan persamaan berikut (Sulistyanto, 2008:227):

DAit $=($ TAit/Ait -1$)-$ NDAit

Keterangan:

DAit = Discretionary Accruals perusahaan i pada tahun t.

\section{Definisi Perencanaan Pajak}

Perencanaan Pajak (Tax Planning) merupakan proses pengorganisasian usaha wajib pajak atau sekelompok wajib pajak sedemikan rupa sehingga utang pajaknya, baik pajak penghasilan atau pajak lainnya berada dalam posisi yang paling rendah sepanjang ini dimungkinkan oleh ketentuan peraturan perundang-undangan perpajakan. Perencanaan pajak dapat diukur dengan menggunakan rumus tax retention rate (tingkat retensi pajak) yang menganalisis sebuah ukuran dari efektivitas manajmen pajak pada laporan keuangn perusahaan tahun berjalan. Tax retention rate (tingkat retensi pajak) dihitung sebagai berikut: 
TRR $=\frac{\text { Net Income it }_{\text {Pretax Income }}(\mathrm{EBIT}) \text { it }}{\text { Pit }}$

Keterangan:

TRR $\quad=$ Tax Retention Rate (tingkat retensi pajak) perusahaan i pada tahun t.

Net Income it = Laba bersih perusahaan i pada tahun $\mathrm{t}$.

Pretax Income (EBITit) = Laba sebelum pajak perusahan $\mathrm{i}$ tahun $\mathrm{t}$.

\section{Definisi Leverage}

Noviantari (2016) menyatakan bahwa leverage adalah rasio yang menunjukkan seberapa besar utang atau modal membiayai aktiva perusahaan. Pengembangan dan perluasan usaha tentunya tidak terlepas dari penggunaan utang. Pinjaman dari kreditur seperti bank ataupun lembaga/organisasi lainnya tentu berperan dalam penggunaan utang dalam hal perkembangan usaha. Pada rasio ini dijelaskan pentingnya penggunan utang yang dapat diihat dari aktiva perusahaan yang didukung oleh utang. Harahap (2015) menjelaskan bahwa rasio leverage dapat digunakan untuk melihat seberapa besar risiko keuangan yang dihadapi oleh suatu perushaan perusahaan. Dari pendapat diatas maka dapat diartikan bahwa leverage nerupakan rasio yang menunjukan seberapa besar resiko keuangan suatu perushaan dengan memperhitungkan pembiayaan aktiva dari utang atau modal.

Leverage diproksikan dengan Debt to Asset Ratio (DAR). Menurut Kasmir (2014:155), DAR dapat dihitung sebagai berikut:

\section{Totang Hutang}

DAR $=$ Total Aset 


\section{Definisi Ukuran Perusahaan}

Variabel bebas yang berikutnya yaitu mengenai ukuran perusahaan. Murhadi (2013) menyatakan bahwa ukuran perusahaan dapat diukur dengan mentransformasikan total aktiva ke dalam bentuk logaritma natural. Perhitungan ukuran perusahaan menggunakan Log Natural total aktiva dengan tujuan menjurangi fluktuasi data yang berlebih. Penggunaan Log Natura/ pada jumlah aset dengan nilai ratusan miliar bahkan triliun akan disederhanakan, tanpa mengubah proporsi dari jumlah aset yang sesungguhnya. Sehingga perhitungan variabel ukuran perusahaan diukur melalui (Kurniasih, 2012:150):

Size $=$ Ln (Total Asset $)$

\section{Definisi Profitabilitas}

Indikator yang digunakan untuk menilai kinerja manajemen dalam mengelola aset ataupun kekayaan yang dimiliki oleh perusahaan adalah profitabilitas. Pengukuran profitabilitas dalam penelitian ini dengan skala rasio return on assets (ROA). Kemampuan perusahaan dalam menghasilkan laba bersih berdasarkn tingkat aktiva tertentu dapat diukur menggunakan rasio ini. Sehingga perhitungan profitabilitas dapat dirumuskan sebagai berikut (Hanafi dan Halim, 2016:81):

\section{Laba Bersih \\ $\mathrm{ROA}=$ Total Aset}

\section{Hubungan Antar Variabel \\ Pengaruh Perencanaan Pajak terhadap Manajemen Laba}

Penelitian yang dilakukan Sumomba (2010) berhasil membuktikan bahwa perencanaan pajak yang dihitung dengan tingkat retensi pajak mampu mengindikasi adanya praktik manajemen laba dan merupakan salah satu respon atas perubahan pada tariff pajak dari 28 persen ke 25 persen sesuai dengan UU No. 36 Tahun 2008. Sejalan dengan penelitian Sumomba (2010), penelitian dari Sarasmita (2016) membuktikan bahwa beberapa variabel seperti perencanaan pajak juga berpengaruh positif terhadap variabel manajemen laba.

\section{Pengaruh Leverage terhadap Manajemen Laba \\ Perusahaan dengan persentase levergae yang tinggi menunjukan proporsi hutang yang lebih tinggi jika dibandingjan dengan proporsi aset, hal ini akan cebderung menyebabkan manipulasi seperti manajemen laba. Hal tersebut berguna untuk menutupi hutang yang tinggi dengan laba yang tinggi pula agar investor tetap tertarik untuk berinvestasi di perusahaan tersebut. \\ Pengawasan yang kurang dapat menjadi salah satu penyebab tingginya angka leverage dan tentunya memicu risiko manajer dalam melakukan tindakan oppurtunistic seperti praktik manajemen laba agar kinerja mereka tetap dapat dipertahankan dimata pemegang saham maupun publik. Jika perusahaan tidak dapat menggunakan dana yang dimiliki secara efisien maka akan menyebakan utang yang besar bagi perusahan sehingga perusahaan berisiko kesulitan membayar utang. Semakin tingginya tingkat hutang yang dimiliki oleh suatu perusahaan, maka dapat memicu manajemen dalam melakukan manipulasi laba untuk menjaga citra perusahaan di mata masyarakat dan investor tetap mau berinvestasi di perusahaan tersebut. Hasil penelitian yang dilakukan oleh Ramadhani (2017) menunjukkan bahwa leverage berpengaruh positif terhadap manajemen laba.}

\section{Pengaruh Ukuran Perusahaan terhadap Manajemen Laba}

Dilihat dari ukuran perusahaan, dorongan untuk melakukan manajemen laba pada perusahaan besar lebih rendah dibandingkan dengan perusahaan berskala kecil dikarenakan pemegang saham dan pihak eksternal akan lebih kritis menilai perusahaan dengan ukuran besar. Penelitian yang dilakukan Muliati (2011) serta Nariastiti dan Ratnadi 
(2014) menemukan bahwa ukuran perusahaan dengan manajemen laba berpengaruh negatif. Motivasi yang rendah dalam praktik manajemen laba di perusahaan besar dipicu oleh pandangan pemegang saham dan pihak-pihak eksternal perusahaan yang lebih kritis dibandingkan pada perusahaan kecil.

\section{Pengaruh Profitabilitas terhadap Manajemen Laba}

Bonus maupun kompensasi menjadi salah satu motivasi manajer dalam melakukn praktik manajmen laba. Bonus Plan Hypothesis menjelaskan saat laba yang diperoleh perusahaan pada tahun berjalan berada di bawah persyaratan atas kinerja dalam memperoleh bonus, manajemen cenderung akan menaikan laba agar tingkat minimum untuk memperoleh bonus dapat tercapai dan jika pada tahun itu kinerja seorang manajer menerima nilai lebih yang mengisyaratkn untuk mendpatkan bonus, maka manajer akan mengelolah dan menjatur dalam melaporkan laba yang tinggi (Wiyadi, 2015). Hasil penelitian yang dilakukan oleh Hasty et al. (2017) menemukan bahwa profitabilitas berpengaruh positif terhadap manajemen laba.

\section{Kerangka pemikiran}

Laba merupakan ukuran paling sederhana yang dilihat stakeholder untuk dapat mengambil keputusan. Laporan keuangan dari sebuah perusahaan dapat dijadikan acuan dalam menilai kinerja dari manajemen sebuah perusahaan. Laporan keuangan juga memperlihatkan kondisi perusahaan yang memiliki kinerja yang baik ataupun tidak, kondisi tersebut dapat dijadikan bahan pertimbangan oleh stakeholder dalam pengambilan keputusan. Oleh karena pentingnya laporan keuangan maka banyak perusahaan yang berusaha untuk mengubah dan mengaturnya.

Manajemen laba merupakan tindakan mengatur laba yang paling aman karena kegiatan manajemen laba merupakan hal yang legal dan tidak melanggar prinsip akuntansi diterima umum, tetapi untuk jangka panjang konsekuensi yang terjadi adalah hilangnya dukungan dari shareholders yang berdampak pula pada kewaspadaan dan kecurigaan yang besar terhadap laporan dan kegiatan perusahaan. Pada perusahaan pajak adalah salah satu motivasi manajemen dalam melakukan praktik manajemen laba. Dengan tujuan untuk mempengaruhi besarnya pajak yang harus dibayar perusahaan yang dilakukan dengan cara menurunkan laba untuk mengurangi beban pajak yang harus dibayar. Wajib pajak dapat memanfaatkan perpajakan usaha dan penghasilan dalam sebuah perencanaan pajak dengan catatan bahwa perencanaan pajak yang dilakukan tidak melanggar konstitusi maupun undang-undang terkait.

Motivasi terjadinya praktik manajemen laba juga dapat datang dari tingkat leverage perusahaan. Tingginya angka leverage pada perushaan menunjukan liabilitas yang lebih besar dibandingkan aktiva ataupun aset yang dimiliki oleh perusahaan, risiko dan tekanan pun menjadi lebih besar dirasakan oleh perusahaan.Meningkatnya rasio leverage pada suatu perusahaan maka dapat semakin tinggi pula tingkat rsiko yang dihadapi perusahaan karena investor cenderung tertarik pada perusahaan dengan rasio leverage yang lebih rendah. Selain laporan keuangan, ukuran perusahaan akan mempengaruhi struktur pendanaan perusahaan. Kecenderungan yang terjadi pda perusahaan besar adalah perlunya dana yang lebih banyak dibandingkan perusahaan dengan skala yang lebih kecil. Keperluan dana yang cukup besar dapat mengindikasikan bahwa perusahaan menginginkan pertumbuhan laba dan juga pertumbuhan tingkat pengembalian saham. Ini merupakan salah satu alas an ukuran perusahaan yang menunjukkan besar kecilnya perusahaan merupakan faktor penting dalam pembentukan manajemen laba. Semakin besar ukuran perusahaan biasanya informasi yang tersedia untuk investor dalam pengambilan keputusan semakin banyak dan memperkesil kemungkinan terjadinya asimetri informasi yang bisa menyebabkan terjadnya praktik manajemen laba pada perusahaan.

Kemampuan perusahaan dalam menghasilkan tingkat laba (profitabilitas) yang baik juga menjadi pandangan penting bagi sebuah perusahaan. Nilai pada rasio ini digunakan sebagai salah satu indikator dalam mengukur kinerja sebuah perusahaan. Meningkatnya 
profitabilitas sejalan dengan kinerja perusahaan dalam menghasilkan laba yang meningkat pula. Karenanya hubungan antara profitabilitas dengan manajemen laba adalah ketika profitabilitas yang diperoleh perusahaan kecil pada periode waktu tertentu akan memotivasi perusahaan untuk melakukan manajemen laba salah satunya dengan meningkatkan pendapatan yang diperoleh yang berdampak pada terlihatnya pergerakan saham yang baik dan dapat mempertahankan investor.

Berdasarkan urain kerangka pemikiran tersebut, maka penelitian ini akan menjelaskan Pengaruh Faktor- faktor seperti perencanaan pajak, leverage, ukuran perusahaan dan profitabilitas terhadap manajemen laba.

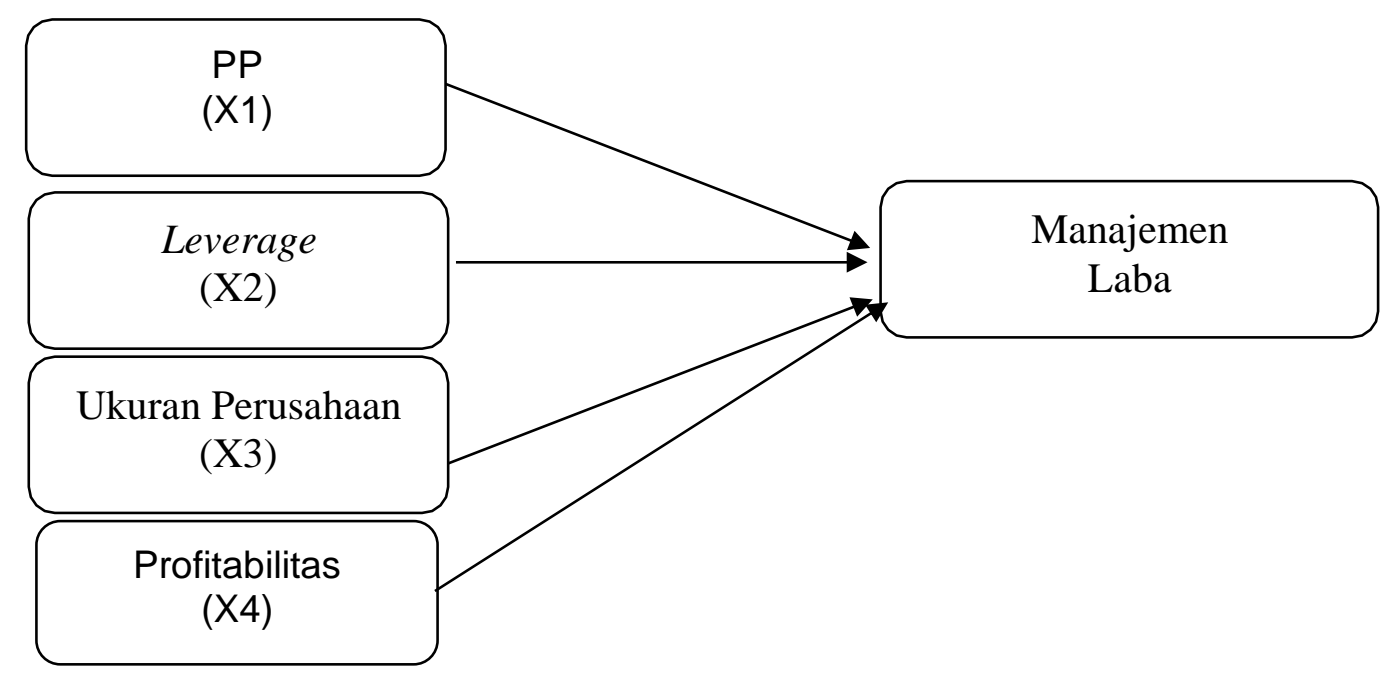

Gambar 1

Dari penjabaran tersebut maka dihasilkan tiga hipotesis penelitan yaitu: $\mathrm{H}_{1}$ : Ada pengaruh perencanaan pajak terhadap manajemen laba

$\mathrm{H}_{2}$ : Ada pengaruh leverage terhadap manajemen laba

$\mathrm{H}_{3}$ : Ada pengaruh ukuran perusahaan terhadap manajemen laba

$\mathrm{H}_{4}$ : Ada pengaruh profitabilitas terhadap manajemen laba

\section{METODE}

Populasi dalam penelitian ini adalah perusahaan yang berada di sektor manufaktur yang telah tercatat di papan utama IDX. Jumlah perusahaan yang terdaftar dan dapat memenuhi ketentuan yaitu sebanyak 66 perusahaan, penentuan sampel menggunakan metode non purposive sampel dengan menetapkan beberapa kriteria diantaranya perusahaan yang terdaftar pada sektor manufaktur di BEI selama periode penelitian (20172019), perusahaan yang memiliki kelengkapan data pada laporan keuangannya sesuai dengan variabel pada penelitian ini.

Metode pengumpulan data yang digunakan adalah metode dokumentasi yakni teknik pengumpulan data dengan cara mengumpulkan data-data yang diperlukan pada penelitian yang diperoleh baik dari laporan keuangan tahunan maupun sustainability report yang dipublikasikan. Pengumpulan data dalam penelitian ini dilakukan dengan cara melakukan penelusuran laporan tahunan 2017-2019 di www.idx.co.id, Studi pustaka atau literatur melalui buku teks, jurnal ilmiah, artikel dan majalah, serta sumber tertulis lainnya yang berkaitan dengan informasi yang dibutuhkan juga dijadikan sumber pengumpulan data. Data yang diamati ialahh data dari periode 2017 hingga 2019 dengan menggunakan metode penggabungan data (pooling data). Pemilihan penggunaan metode pooling karena metode tersebut mempunyai keunggulan yaitu kemungkinan diperolehnya jumlah sampel yang lebih besar yang diharapkan dapat meningkatkan power of test penelitian. 
Dalam penelitian ini metode dan teknik analisis data yang digunakan yaitu analisis regresi linier berganda dengan menggunakan perangkat lunak SPSS versi 23.0 untuk Windows. Tujuannya adalah untuk mendapatkan bukti empiris yang membuktikan hubungan antara variabel bebas dengan variabel terikat, penetapan tingkat signifikan dan diakhiri dengan pembuatan kesimpulan penelitian melalui penerimaan atau penolakan hipotesis. Untuk memperoleh hasil yang lebih akurat pada analisis regresi berganda maka dilakukan asumsi klasik yang harus dipenuhi terlevih dahulu sebelum menggunakn analisis regresi berganda. Regresi linier berganda ini digunakan untuk memproyeksikan dan mencari pengaruh dan hubungan terhadap variabel manajemen laba $(\mathrm{y})$. Berdasarkan variabel perencanaan pajak (X1), leverage (X2), ukuran perusahaan (X3) dan profitabilitas (X4). Untuk menentukan berpengaruh tidaknya variabel-variabel bebas terhadap variabel terikat baik secara parsial maufun simultan, maka dalam penggunaan analsis regresi berganda digunakan uji t (parsial) dan uji F (simultan).

Model analisis yang digunakan adalah model analisis regresi linear berganda. Model ini digunakan untuk mengetahui pengaruh variabel bebas terhadap variabel terikat dengan persamaan sebagai berikut.

$$
Y=\alpha+\beta_{1} X_{1}+\beta_{2} X_{2}+\beta_{3} X_{3}+e
$$

Keterangan:

$\mathrm{Y}=$ Manajemen laba

$\alpha=$ Konstata

$\beta=$ Koefisien Regresi $X_{1}=$ PerencanaanPajak

$\mathrm{X}_{2}=$ Leverage

$\mathrm{X}_{3}=$ Ukuran perusahaan

$\mathrm{X}_{4}=$ Profitabilitas

\section{HASIL DAN PEMBAHASAN}

\section{Asumsi Klasik}

Berdasarkan hasil uji normalitas menggunakan uji test Kolmogorov-Smirnov dengan angka Unstandardized Residual pada kolom Asmyp. Sig. (2-tailed) adalah 0,187 dimana nilai signifikan lebih besar dari 0,05 yang berarti data residual dalam penelitian ini telah berdistribusi normal.

Hasil uji multikolinieritas menjelaskan bahwa nilai dari variabel Perencanaan Pajak (PP) memiliki nilai tolerance sebesar 0,990 dan nilai VIF sebesar 1,010, variabel Leverage (L) memiliki nilai tolerance sebesar 0,975 dan nilai VIF sebesar 1,025 , variabel Ukuran Perusahaan (UP) memiliki nilai tolerance sebesar 0,944 dan nilai VIF sebesar 1,059, variabel Profitabilitas $(P)$ memiliki nilai tolerance sebesar 0,930 dan nilai VIF sebesar 1,075 . Sehingga seluruh variabel memiliki nilai tolerance yang lebih dari 0,10 (10 persen) ataupun nilai VIF yang kurang dari 10. Hal ini menunjukan bahwa tidak terjadi multikolinieritas antara variabel bebas dalam model regresi.

Uji autokorelasi menunjukkan bahwa nilai durbin-watson sebesar 1,858 . Nilai dL dan Du dengan $\alpha=5 \%$ pada $n=198$ dan $k=4$ masing-masing sebesar 1,7263 dan 1,8087. Hasil uji autokorelasi dengan metode durbin-watson berada diantara du $=1,8087$ dan 4-du $=2,1913$ yang berada pada kisaran $d u<d w<(4-d u)$ atau $(1,8087<1,8580<2,1913)$ yang berarti tidak terdapat autokorelasi sehingga model ini layak digunakan untuk analisis selanjutnya.

Selanjutnya hasil uji heteroskedastisitas menggunakan uji glejser dapat disimpulkan bahwa nilai signifikan dari masing-masing variabel independen yang terdiri dari Perencanaan Pajak (PP) 0,863, Leverage (L) 0,263, Ukuran Perusahaan (UP) 0,468, Profitabilitas 0,907 terhadap Earning Management (EM) memiliki nilai signifikan lebih dari 0,05. Hal ini menunjukkan bahwa seluruh variabel independen tidak ada yang berpengaruh signifikan terhadap nilai absolute residual, atau dengan kata lain berdasarkan hasil pengujian yang 
telah dilakukan menunjukkan bahwa dalam penelitian ini tidak terjadi heteroskedastisitas.

\section{Uji Regeresi Linier Berganda}

Model analisis linier berganda digunakan untuk mengetahui pengaruh perencanaan pajak, leverage, ukuran perusahaan dan profitabilitas terhadap manajemen laba, dalam pengujian ini metode yang digunakan yaitu model analisis regresi linier berganda. Dalam menganalisis data dibantu oleh program aplikasi komputer (SPSS) 23.0 for Windows., dari uji yang telah dilakukan diperoleh hasil sebagai berikut.

\section{Tabel 2}

\section{Ouput Hasil Analisis Regresi Berganda}

\begin{tabular}{|l|c|c|c|l|}
\hline \multicolumn{1}{|c|}{ Variabel } & Koefisien & t-statistik & Sig & Kesimpulan \\
\hline Constant & 0.19 & 0.191 & 0.849 & \\
\hline $\begin{array}{l}\text { Perencanaan } \\
\text { Pajak }\end{array}$ & 0.001 & 0.098 & 0.922 & H1 ditolak \\
\hline Leverage & -0.024 & -1.008 & 0.315 & H2 ditolak \\
\hline $\begin{array}{l}\text { Ukuran } \\
\text { Perusahaan }\end{array}$ & -0.002 & -0.614 & 0.540 & H3 ditolak \\
\hline Profitabilitas & 0.266 & 4.634 & 0.000 & H4 diterima \\
\hline
\end{tabular}

Hipotesis yang pertama adalah "ada pengaruh positif perencanaan pajak terhadap manajemen laba". Hasil pada Tabel 2 menyatakan bahwa Ho ditolak dengan kesimpulan bahwa perencanaan pajak tidak berpengaruh terhadap manajemen laba. Kesimpulan tersebut diperoleh dari nilai sig $(0,922>0,05)$.

Kemudian hipotesis penelitian yang kedua yaitu "ada pengaruh positif leverage terhadap manajemen laba". Berdasarkan hasil penelitian dengan bantuan aplikasi SPSS 23.0 for windows, hasil pada Tabel 2 menyatakan bahwa Ho ditolak dengan kesimpulan bahwa leverage tidak berpengaruh terhadap manajemen laba. Kesimpulan tersebut diperoleh dari nilai sig $(0,315>0,05)$.

Hipotesis penelitian yang ketiga yaitu "ada pengaruh negatif ukuran perusahaan terhadap manajemen laba". Hasil pada Tabel 2 menyatakan bahwa Ho ditolak dengan kesimpulan bahwa ukuran perusahaan tidak berpengaruh terhadap manajemen laba. Kesimpulan tersebut diperoleh dari nilai sig $(0,540>0,05)$.

Selanjutnya hipotesis penelitian yang terakhir yaitu "ada pengaruh positif antara profitabilitas terhadap manajemen laba". Hasil pada Tabel 2 menyatakan bahwa Ho diterima dengan kesimpulan bahwa profitabilitas berpengaruh positif terhadap manajemen laba. Kesimpulan tersebut diperoleh dari nilai sig $(0,000<0,05)$.

Berdasarkan hasil uji koefisien determinasi menunjukkan bahwa koefisien determinasi (Adjusted $R$ Square) sebesar 0,093 x $100=9,3 \%$. Hal ini berarti 9,3\% variasi dari Manajemen Laba (Earning Management) mampu dijelaskan oleh variabel perencanaan pajak (PP), leverage (L), ukuran perusahaan (UK), profitabilitas (P). Sedangkan sisanya $100 \%-9,3 \%=90,7 \%$ dijelaskan oleh variabel-variabel lain diluar metode penelitian. Dilihat dari Standard eror of the estimate sebesar 0,07527 semakin kecil angka standard eror of the estimate akan membuat model regresi semakin tepat dalam memprediksi variabel dependen.

Dari hasil regresi yang disajikan pada Tabel 2 didapatkan persamaan regresi linier berganda sebagai berikut:

$$
E M=0,019+0,001 P P-0,024 L-0,002 U P+0,266 P
$$

Hasil penelitian menunjukkan bahwa perencanaan pajak tidak memiliki pengaruh terhadap manajemen laba yang menunjukan besar atupun kecilnya perencanaan pajak tidak mempunyai pengaruh terhadap manajemen laba. Perencanaan pajak tidak berpengaruh terhadap manajemen laba dapat disebabkan karena self interest management lebih diperhatikan oleh manajemen perusahaan yang pada perusahaan manufaktur dibagi 
menjadi beberapa divisi dan departement sehingga kepentingan yang muncul lebih kepada reward atau bonus atas kinerja baik yang dapat dicapai dibandingkanperencanaan pajak yang justru menjadi kepentingan prinsipal. Perencanaan pajak seringkali menjadi keinginan pemilik perusahaan, dimana pemilik perusahaan menginginkan dividen yang tinggi, dengan mengeluarkan biaya-biaya serendah mungkin. Sehingga ada tidaknya perencanaan pajak tidak mempengaruhi manajemen dalam melakukan manajemen laba. Hasil penelitian ini sama dengan hasil penelitian yang dilakukan Putri (2016), Achyani (2019) serta Aditama dan Purwaningsih (2014) menunjukkan bahwa perencanaan pajak tidak berpengaruh terhadap manajemen laba.

Hasil selanjutnya menunjukkan bahwa tidak berpengaruhnya leverage terhadap manajemen laba, tidak adanya pengaruh dapat disebabkan karena sebuah perusahaan dengan rasio leverage yang tinggi berarti memiliki utang yang tinggi pula, total utang yang tinggi menghadapkan perusahaan pada risiko default yang tinggi pula apabila perusahaan tidak dapat memenuhi kewajiban dan tanggung jawab atas utang yang dimiliki. Pemenuhan kewajiban yang tetap harus dilakukan tidak dapat diselesaikan dengan tindakan manajemn laba. Hal ini berarti jika leverage perusahaan mengalami peningkatan, maka tingkat manajemen laba yang dilakukan akan tetap atau konstan. Hasil penelitian ini sama dengan hasil penelitian yang dilakukan oleh Robert Jao (2010) dan penelitian Jao dan Pagulung (2011).

Ukuran perusahaan tidak berpengaruh terhadap praktik manajemen laba diduga karena investor tidak memandang kritis besar kecilnya total aset yang dimiliki perusahaan, pertimbangan investor terkait return dan risk tidak mengacu pada besar ataupun kecil aktiva yang dimiliki oleh suatu perusahaan sehingga variabel ini tidak menjadi motivasi manajemen dalam melakukan praktik manajemen laba. Penyebab kedua adalah investor telah menaruh kepercayaan pada perusahaan-perusahaan go publik baik yang berukuran besar ataupun kecil yang telah lama terdaftar di BEI dimana besar atau kecilny perusahaan harus mengikuti regulasi yang sama sesuai dengan ketentuan pasar modal. Hasil penelitian ini sejalan dengan hasil penelitian yang dilakukan oleh Sosiawan (2012) dan Gunawan, dkk. (2015).

Pengaruh positif ditunjukan oleh profitabilitas. semakin tinggi rasio profitabilitas yang dimiliki oleh sebuah perusahaan maka akan memberikan pengaruh positif akan adanya tindakan praktik manajemen laba. Return On Assets yang tinggi mencerminkan penggunaan aset yang maksimal untuk memperoleh keuntungan. Ketika laba yang dihasilkan perusahan pada satu periode sangat tinggi, maka akan terdapat kemungknan terjadi penurunan laba pada periode waktu berikutnya. Pernyataan ini didukung oleh penelitian Puspitasari (2019) dan Winingsih (2017).

\section{SIMPULAN}

\section{Simpulan}

Maka kesimpulannya ada 1 hipotesis yang telah diterima dan 3 hipotesis yang telah ditolak, yaitu perencanaan pajak yang tidak memiliki pengaruh terhadap manajemen laba, leverage yang tidak berpengaruh begitu juga dengan ukuran perusahaan. Sementara hasil berbeda diperlihatkan dari hasil uji variabel profitabilitas yang memiliki pengaruh positif terhadap terjadinya manajemen laba.

\section{Implikasi Penelitian}

Investor dapat mempertimbangkan dan lebih memperhatikan profitabilitas perusahaan yang ditunjukan, profitabilitas yang tinggi dapat mengindikasikan adanya pengaruh positif terhadap manajemen laba, sehingga investor dapat mengambil keputusan bisnis yang lebih baik. 


\section{REFERENSI}

Afrizal, Franky, 2018. Pengaruh Pajak Tangguhan, Perencanaan Pajak dan Leverage Terhadap Manajemen Laba (Studi Empiris Pada Perusahaan Manufaktur yangTerdaftar di Bursa Efek Indonesia Tahun 2014-2016). Jom Feb. Volume I. Edisi I. Faculty of Economic and Bussines Riau University. Pekanbaru.

Agustia, Dian. 2013. Pengaruh Faktor Good Corporate Governance, Free Cash Flow dan Leverage Terhadap Manajemen Laba. Jurnal Akuntansi dan Keuangan Vol. 15, No. 1, Mei 2013, hlm. 27-42.

Agustin Yuliana dan Ita Trisnawati. 2015. Pengaruh Auditor dan Rasio Keuangan Terhadap Manajemen Laba. Jurnal Bisnis dan Akuntansi. ISSN 1410-9875. Vol 17 No 1: 33-45.

Agus Sartono. 2010. Manajemen Keuangan Teori dan Aplikasi. Edisi 4. Yogjakarta: BPFE.

Anggana, Gea Rafdan dan Andri Prastiwi. 2013. Analisis Pengaruh Corporate Governance Terhadap Praktik Manajemen Laba. Diponegoro Journal Of Accounting. ISSN Online: 2337-3806. Vol 2 (3).

Dechow, P.M., Sloan, R.G., Sweeney, A.P, 1995. Detecting Earnings

Management. The Accounting Review 70, 193-225.

Dewi, Eva Rafika, Elva Nuraina, Nik Amah. 2017. Pengaruh Tax Planning dan Ukuran Perusahaan Terhadap Manajemen Laba (Studi Empiris Pada Perusahaan Properti Yang Terdaftar Di Bursa Efek Indonesia). Madiun: e ISSN: 23379723.

Dewi, M. A. A., \& Suryanawa, I. K. 2019. Pengaruh Leverage, Bonus Plan, Ukuran Perusahaan, dan Profitabilitas pada Praktik Perataan Laba. E-Jurnal Akuntansi, 26(1), 58-84.

Guna, W dan Herawaty, A. 2010. Pengaruh Mekanisme Good Corporate Governance, Independensi Auditor, Kualitas Audit dan Faktor Lainnya dalam Manajemen Laba. Jurnal Bisnis dan Akuntansi, Vol. 12, No. 1.

Handayani, F., \& Fuad, F. 2015. Faktor Yang Berpengaruh Terhadap Perataan Laba Perusahaan Otomotif Yang Terdaftar di Bursa Efek Indonesia (BEI) periode 20092012. Doctoral dissertation. Fakultas Ekonomika dan Bisnis.

Handayani, Sri dan Agustono Dwi Rachadi. 2009. Pengaruh Ukuran Perusahaan Terhadap Manajemen Laba, Jurnal Bisnis dan Akuntansi, Vol 11, No. 1.

Hanafi, M. M., dan Halim, Abdul. 2016. Analisis Laporan Keuangan. Edisi Kelima. Yogyakarta: UPP STIM YKPN 
Hasty \& Herawaty. 2017. Pengaruh Struktur Kepemilikan, Leverage, Profitabilitas Dan Kebijakan Dividen terhadap Manajemen Laba dengan Kualitas Audit Sebagai Variabel Moderasi (Studi Empiris pada Perusahaan Manufaktur yang Terdaftar di Bursa Efek Indonesia Tahun 2013-2015). Jurnal Media Riset Akuntansi, Auditing, dan Informasi, Vol.17, No.1, April 2017: 1-16.

Hoffman, Jr, William H. 1961. The Theory of Tax Planning, Journal The Accounting Review, Vol. 36, No. 2.

Jensen, Michael C. dan dan W.H.Meckling. 1976. Theory of The Firm: Managerial Behavior, Agency Cost and Ownership Structure. Journal of Financial Economics 3, pp. 305-360.

Jao, Robert dan Gagaring Pagulung. 2011. Pengaruh Corporate Governance, Ukuran Perusahaan, dan Leverage Terhadap Manajemen Laba Perusahaan Manufaktur Indonesia. Jurnal Akuntansi dan Auditing, 8 (1), h: 1-94.

Kurniawan, M. S., Latifah, S. W., \& Zubaidah, S. 2012. Pengaruh return on asset, ukuran perusahaan dan financial leverage terhadap tindakan perataan laba (studi empiris pada perusahaan sektor keuangan yang terdaftar di BEI). Journal of Accounting and Investment. 13(2), 68-82.

Muliati, Ni Ketut. 2011. Pengaruh Asimetri Informasi Dan Ukuran Perusahaan Pada Praktik Manajemen Laba Di Perusahaan Perbankan Yang Terdaftar Di Bursa Efek Indonesia. Tesis. Universitas Udayana Denpasar, Bali.

Phillips, J., M. Pincus, and S.O.Rego. 2003. Earnings Management: New Evidence Based on Deferred Tax Expense. The Accounting Review, 78.

Puspita, Prita. 2014. Penerapan Perencanaan Pajak (Tax Planning) Pada Perusahaan Industri Pengolahan Kayu di Kabupaten Purbalingga. Skripsi. Fakultas Ekonomi Muhamadiyah Purwokerto.

Purnama, Dendi. 2017. Pengaruh Profitabilitas, Leverage, Ukuran Perusahaan, Kepemilikan Institusional dan Kepemilikan Manajerial Terhadap Manajemen Laba. Jurnal Riset Keuangan dan Akuntansi. Vol 3. No. 1. Universitas Kuningan.

Purwaningrat \& Suaryana. 2015. Pengaruh Perubahan Earning Per Share, Debt to Equity Ratio, dan Ukuran Perusahaan pada Return Saham. E-Jurnal Akuntansi. Universitas Udayana. 10(2), 444-455.

Prasetyo, A. 2013. Pengaruh Leverage dan Profitabilitas Terhadap Harga Saham Pada Perusahaan Manufaktur Yang Terdaftar di Bursa Efek Indonesia Tahun 20092011. Jurnal. Universitas Maritim Raja Ali Haji Tanjung pinang.

Ramadhani, Fitria, Sri Wahjuni Latifah, dan Endang Dwi Wahyuni. 2017. Pengaruh Capital Intencity Ratio, Free Cash Flow, Kualitas Audit, dan Leverage Terhadap Manajemen Laba. Jurnal IImiah Akuntansi, 15(2).

Restuwulan. 2013. Pengaruh Asimetri Informasi dan Ukuran Perusahaan Terhadap Manajemen Laba. Skripsi. Universitas Widyatama: Bandung.

Robert, Jao. 2010. Pengaruh Corporate Governance, Ukuran Perusahaan dan Leverage 
Terhadap Manajemen Laba Perusahaan Manufaktur Indonesiall. Skripsi. Universitas Hasanuddin.

Scott, William, R. 2009. Financial Accounting Theory. fifth Edition. Canada Prentice Hall

Suhartanto, D. 2015. Pengaruh Ukuran Perusahaan, Profitabilitas, Leverage, Kepemilikan Publik, Perubahan Harga Saham dan Risiko Bisnis terhadap Manajemen Laba Perusahaan Publik Sektor Keuangan. Jurnal Ekonomi Bisnis .Volume 20 No. 1, April 2015, 20(1), 1-7.

Sulistyanto, H. Sri. 2008. Manajemen Laba, Teori dan Model Empiris. Jakarta: Grasindo.

Van Horne, James C. and John M. Wachowicz. 2007. Fundamentals of Financial Management, Prinsip-Prinsip Manajemen Keuangan. Jakarta: Salemba Empat.

Wardani, Dewi Kusuma dan Desifa Kurnia Santi. 2018. Pengaruh Tax Planning, Ukuran Perusahaan, Corporate Social Responsibility (CSR) Terhadap Manajemen Laba. Jurnal Akuntansi, 6(1): 11-24.

Watts, Ross L., and Jerold L. Zimmerman. 1986. Possitive Accounting Theory. The Accounting Review.

Wild, John J., K. R. Subramanyam and Robert F. Hasley. 2004. Financial Statement Analysis, 8th ed. Boston: Mc.Graw-Hill.

Wildaman, Herawati, Muslim. 2013. Pengaruh Profitabilitas, Leverage dan Asimetri Informasi terhadap Manajemen Laba (Studi Empiris pada Perusahaan Manufaktur yang terdaftar di Bursa Efek Indonesia Periode 2009 -2013). Universitas Bung Hatta. Jakarta.

Widyastuti, Tri. 2009. PengaruhStruktur Kepemilikan dan Kinerja Keuangan Terhadap Manajemen Laba (Studi pada Perusahaan Manufaktur di BEI). Jurnal Maksi, Vol.9 (1), 30-41.

Wirakusuma, D. K. 2016. Pengaruh Perencanaan Pajak, Kepemilikan Manajerial dan Ukuran Perusahaan terhadap Praktek Manajemen Laba. E-Jurnal Akuntansi Universitas Udayana.

Wika, Septian. 2011. Pengaruh Corporate Governance, Bonus Plans, Debtcovenant, dan Firm Size Terhadap Manajemen Laba. Skripsi. Universitas Diponegoro.

Wolk, H. I, and Michael G. Tearney. 1997. Accounting Theory: A Conceptual and Institusional Approach 4 th ed. Ohio, South-Western College Publishing.

$\underline{w w w . i d x . c o . i d}$ 